\title{
THE ANALYSIS OF MANGROVE FOREST MANAGEMENT SUSTAINABILITY IN DAMAS BEACH, TRENGGALEK
}

\author{
Purwanti Pudji*, Indrayani Erlinda, Fattah Mochammad \\ Socio-Economic Department, Faculty of Fisheries and Marine Sciences, \\ University of Brawijaya, Indonesia \\ *E-mail: pudjipurwanti@gmail.com
}

\begin{abstract}
It is reported that the mangrove forest in Damas Beach has suffered severe damage. This forest damage is caused by the conversion of land functions into coconut plantations and agricultural activities. Nevertheless, several activities of mangrove forest management awareness have been carried out. This socialization is an effort to restore the function of mangrove forests as a counterweight to the coastal ecosystem. The targets of this activity include the communities around mangrove forests, village-level policy makers, community leaders, primary school children as future generations, as well as the teachers. Therefore, the purpose of this study is to analyze the sustainability in mangrove forest management after the awareness raising activities took place. The data analysis used in this study is RAPmangrove which consists of a Multi-Dimensional Scaling analysis, Monte Carlo, and leverage. The sustainability of the mangrove forest ecosystem in Damas Beach is in the category of unsustainable because it experiences a change of function. The activities to change the function of mangrove forest lead to several issues of social conflict in its management. By that, the efforts that must be done to overcome this problem are mangrove rehabilitation, advanced community awareness building, mangroves management skill improvement, and arranging the ecosystem management plans of Damas Beach mangrove forest.
\end{abstract}

\section{KEY WORDS}

Sustainability, management, awareness, mangrove.

The damage to mangrove forests in Damas Beach, Trenggalek Regency, East Java, Indonesia, tends to be caused by the behavior of local communities who consider that plantation crops provide more economic benefits compared to mangroves. This assumption forced the mangrove forest area in Damas Beach to drastically shrink; the area was replaced to be used as a coconut plantation and agricultural activities. The activity of changing the function of mangrove forest into an area that is considered to provide higher economic value is also found in other areas. In central Vietnam coastal area, the mangrove forest in 1990 has been used as a shrimp farming area. As a result, this shrimp cultivation development damaged the mangrove forests and caused environmental degradation as well as water pollution so that the shrimp production is no longer optimal. Consequently, the condition of the community becomes poorer (Hue and Scott, 2007). The community on the Akassa Delta Niger Island also shows that the dependence on the use of mangrove forest resources is very high. Almost all the coastal households are involved in activities that require raw materials from wood from mangrove forests (Eleanya et al, 2015).

The improvement of mangrove forest environment through mangrove forest rehabilitation activities has been carried out in many places. This mangrove forest rehabilitation shows an improvement in environmental quality which also able to create a better quality of life. In Panay Island, Philippines, there has been a rehabilitation of mangrove forests in some abandoned ponds area. These efforts have increased the Climate Change Mitigation and Adaptation (CCMA) in the coastal zone (Duncan et al, 2016). A study from Paul (2006) showed that the preservation of mangrove forest system in rural Caete Bay is very important to maintain the life quality of rural households. According to Rahman and 
Asmawi (2016), to make the efforts of conserving mangrove forests work well, a very important component such as community participation and awareness is needed.

The activities of mangrove forest rehabilitation also have been carried out in the research area. In 2008, the rehabilitation was carried out at Damas Beach and Cengkrong Beach. The rehabilitation at Cengkrong Beach shows significant results, seeing from the increase in mangrove forests area. On the other hand, the rehabilitation effort performed at Cengkrong Beach is in the form of mangrove ecotourism. The development of mangrove ecotourism in Cengkrong Beach provides employment opportunities for people who live in the surrounding area. Purwanti et al (2017) found that some accessible productive activities done by the committee in Cengkrong mangrove ecotourism are mud crab cultivation, Anadara scallop aquaculture, mangrove plant nurseries, food stalls, as well as boat rental and toilets. In addition, some people who live in the surrounding area of Cengkrong Beach also carry out other productive activities such as crabs hunting, fishing, as well as selling food in stalls.

It is found that the forest rehabilitation activity in Damas Beach was less successful because there was still an expansion of coconut trees plantation in the area. The researchers carried out some awareness efforts through several activities including the introduction of fruit benefits from mangroves as foods for coastal women (Purwanti et al, 2016). This effort is carried out through negotiations with community leaders in Damas Beach through meetings and discussions. There is also an act of awareness building to elementary school students in the Damas Beach area.

Various efforts to realize mangrove forest management have been carried out both for women, communities, community leaders, and elementary school students. Therefore, this study aims to evaluate the sustainability of mangrove forest management on Damas Beach.

\section{MATERIALS AND METHODS OF RESEARCH}

This study took place at Karanggandu Village, Watulimo District, Trenggalek Regency, Indonesia. The management of mangrove forests in the area of Damas Beach, Karanggandu experienced some problems in the conversion of land into coconut plantations so that this study is intended to assess the sustainability of mangrove forest ecosystems. According to Marimin (2002), the determination of the number of respondents (experts) must meet the appropriate requirements that are in accordance with science and authority. The respondents who are selected based on experts or authorities in the field of mangrove management are community leaders, Pokmaswas Kejung Samudra, Pokmaswas Jangkar Bahari, Village Devices, and Teachers of Karanggandu II Elementary School as many as 21 people. The data analysis is done with RAPMangrove which is an adjustment method of RAPfish (Rapid Appraisal of Fisheries) consisting of several analysis techniques (Eunike et al., 2018):

- Multi-Dimensional Scaling (MDS): The ordination technique analyzed by MDS to determine the position of good and bad points. The point objects in MDS will be mapped into two or three-dimensional spaces and attempted as close as possible.

- Monte Carlo (MC): Monte Carlo analysis evaluates the effect of random errors that are performed to predict the ordination value used. Monte Carlo results in this study are presented in the form of scatter plots in 25 replications.

- Leverage: Leverage analysis is done to find out the sensitive attributes in each dimension of sustainability used.

The sustainability specification is viewed from the ecological, economic, social, legal, and institutional dimensions. The analysis of RAPMangrove performed by using $\mathrm{R}$. Dimension and variable software is presented in Table 1 below.

The index value of the sustainability of mangrove forest ecosystem management in the data analysis is grouped into four categories of sustainability status, namely: not sustainable, less sustainable, sufficient, and sustainable (Table 2). 
Table 1 - Dimensions and Sustainability of Mangrove Forest Ecosystems in Damas Beach

\begin{tabular}{|c|c|}
\hline Ecological Dimension & Economic Dimension \\
\hline The suitability of mangrove area allocation & Community income derived from mangrove forest \\
\hline The availability of mangrove tree seeds & ecosystem \\
\hline The diversity of mangrove trees & Job opportunities in the mangrove area \\
\hline Mangrove capacity to resi & ion inventory \\
\hline The & e forest ecosyster \\
\hline The diversity of flora and $c$ & The availability of mangrove forest ecosystem utilization \\
\hline The changes in habitat or organisms and mang & zones \\
\hline le to hun & Training and \\
\hline $\begin{array}{l}\text { The availability of mangrove forest ecosystem } \\
\text { conservation zones }\end{array}$ & $\begin{array}{l}\text { ecosystems through diversification of environmentally } \\
\text { friendly mangrove processed products }\end{array}$ \\
\hline Socia & Legal and Institutional Dimensions \\
\hline Mangrove utiliz & The activeness of mangrove forest ecosystem \\
\hline $\begin{array}{l}\text { Public awareness to conserve mangroves through local } \\
\text { wisdom by planting or conserving mangroves } \\
\text { Community participation in managing mangrove forest } \\
\text { ecosystem }\end{array}$ & $\begin{array}{l}\text { Communication and coordination of management } \\
\text { institutions with relevant institutions in the management of } \\
\text { mangrove forest ecosystem } \\
\text { Mechanisms and rules for managing mangrove forests }\end{array}$ \\
\hline $\begin{array}{l}\text { Community knowledge and perception regarding the } \\
\text { function and benefits of mangrove forest ecosystem }\end{array}$ & $\begin{array}{l}\text { Obedience and compliance in the management } \\
\text { regulation of mangrove forests }\end{array}$ \\
\hline $\begin{array}{l}\text { Community activities that damage mangrove forest } \\
\text { ecosystem }\end{array}$ & $\begin{array}{l}\text { Planning management of mangrove forest ecosystem } \\
\text { Sanctions and law enforcement for communities that } \\
\text { damage mangrove forest ecosystem }\end{array}$ \\
\hline & $\begin{array}{l}\text { The availability of extension agents/field officers to } \\
\text { manage the mangrove forest ecosystem }\end{array}$ \\
\hline & $\begin{array}{l}\text { Local and village government policies regarding the } \\
\text { management of mangrove forest ecosystem }\end{array}$ \\
\hline
\end{tabular}

Source: Karlina et al., (2016); Theresia et al., (2015); Muhsimin et al., (2018); Mukhlisi et al, (2014), and Kapuangan et al., (2016).

Table 2 - Sustainability Category

\begin{tabular}{cc}
\hline Index value & Category \\
\hline $0-25$ & Not sustainable \\
$25-50$ & Less sustainable \\
$50-75$ & Fairly sustainable \\
$75-100$ & Sustainable \\
\hline
\end{tabular}

\section{RESULTS AND DISCUSSION}

Awareness Activities for the Re-Management of Mangrove Forests in Damas Beach. The replanting of mangrove forests in Damas Beach was carried out in 2008. However, the activities of logging mangrove forests to be used as land for coconut trees plantation are still going on. It is known that the efforts to raise public awareness in managing the mangrove forests in Damas Beach also have been done. In 2015, the activities were implemented to introduce the benefits of mangrove forests to coastal ecosystems and the introduction of the benefits of mangrove fruits as food and non-food ingredients. The types of pedada/bogem (Sonneratia $s p$ ) mangrove fruit can be processed into mangrove syrup while the type of Bruguiera sp or Avicenna spp (api-api) mangrove fruit can be used for mangrove flour. This flour can be used as a base to make api-api brownies, api-api crackers, api-api dodol, and fire-fire spongecake (see Purwanti et al, 2016). This activity involved village officials as well as community leaders. Besides that, another awareness activity was to have a negotiation with the key figure or "God Father". This negotiation needs to be done because this man is the chairman of LMDH Argo Lestari who is entrusted by Perhutani to manage the forest in Karanggandu Village. This man also has access to the use of mangrove forests.

As a result of the damaged mangrove ecosystem, floods and landslides occurred on Damas Beach. It is important to note that landslides able to cause damage to coral reefs on Damas Beach. The damage to coral reef ecosystems in Damas coastal area is caused by human behavior; using unsustainable fishing gear and destructing the mangrove forest 
ecosystems (Susilo et al, 2017). In 2017, the efforts to build the awareness of mangrove benefits were made on the coral reef ecosystem. In this activity, the techniques to make artificial coral reefs, as well as the economic and ecological benefits of coral reef planting, were introduced.

Not only that, but the efforts to build an awareness to elementary school students were also initiated through counseling by using model props of mangrove ecosystems management and posters installment. This activity also involved village officials and teachers. It is continued by inviting elementary school students accompanied by teachers to learn to plant mangroves in the mangrove ecotourism area at Cengkrong Beach. Besides that, there was an activity of mangrove seeds planting on Damas Beach.

The Sustainability Analysis of Mangrove Forest Ecosystems in Damas Beach. The results of MDS analysis in RAPMangrove showed the index values of ecological, economic, social, as well as legal and institutional sustainability in the management of Damas Beach mangrove forest ecosystem sequentially by $58.68 \%$ (fairly sustainable), $35.06 \%$ (less sustainable), $46.29 \%$ (less sustainable), and $47.54 \%$ (less sustainable) (Figure 1). There are 10 types of mangroves on Damas Beach including Acanthus illicifolius, Lumnitzera racemosa, Nypa fruticans, Ceriop descandra, Soneratia Alba, Rhizopora mucronata, Aegiceras corniculatum, Rhizopora apiculata, Heritiera globosa and Heritiera littoralis (Purwanti et al., 2016). The mangrove forest ecosystems in Damas Beach experience a land conversion causing a degradation in the function and benefits of mangroves. Susilo et al., (2015) said that the greatest change of land functions is found in the tidal area of Damas River and Gilang River which covers an area of \pm 6.4 hectares to become a plantation area and residential area.

The changes in the area of mangrove forests affect the economic value of coastal communities which are obtained from mangrove ecosystems in the form of crabs, shells, oysters, and other economical fish so as to reduce the livelihood opportunities in the mangrove area. It requires awareness and community participation in the forest management to rejuvenate the condition of Damas Beach mangrove ecosystem through an educational approach. In addition, the government and the community need to develop a plan to manage the mangrove forest ecosystem as well as law enforcement for the perpetrators of mangrove damage. In a multidimensional manner, the sustainability status of the forest management in Damas mangrove forest ecosystem is in the less sustainable category by $46.89 \%$ so that it is necessary to pay attention to sensitive variables to improve the sustainability status.

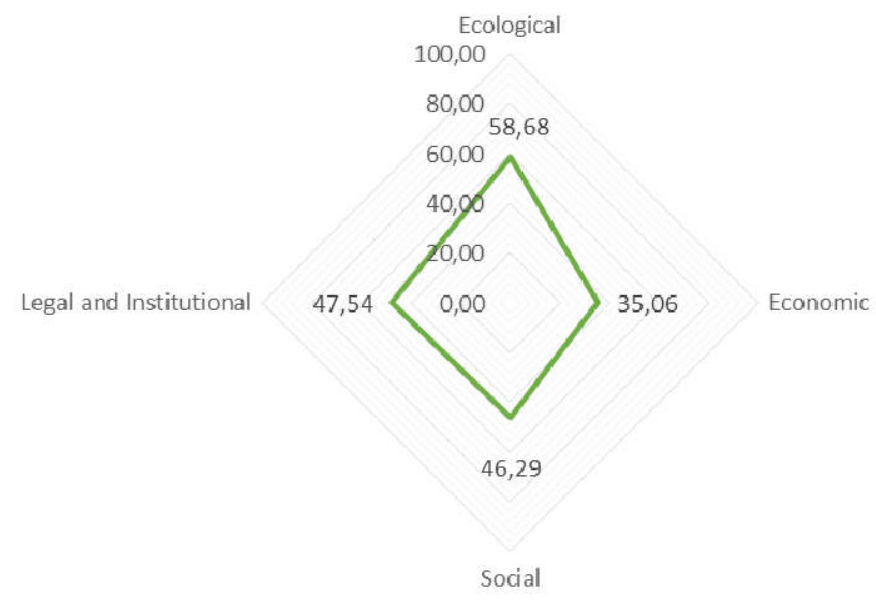

Figure 1 - Kite diagram of a multidimensional sustainability index

The difference between the low sustainability index value between the analysis results from MDS and MC proves that the effect of errors can be avoided (Wibowo et al., 2015). The results of calculation of the difference between MDS and MC shows a low difference in value (Table 3) so that it indicates that MDS has a high level of confidence because of the minimum procedural errors or understanding of indicators and variations in scoring. 
Table 3 - Comparison of MDS and MC Values

\begin{tabular}{cccc}
\hline \multirow{2}{*}{ Dimension } & \multicolumn{2}{c}{ Sustainability Index (\%) } & \multirow{2}{*}{ Difference } \\
\cline { 2 - 3 } & MDS & MC & -0.0000153 \\
Ecological & 58.679113 & 58.67913 & -0.0000019 \\
Economic & 35.057803 & 35.05780 & 0.0000306 \\
Social & 46.288426 & 46.28840 & 0.0000105 \\
\hline Legal and Institutional & 47.536096 & 47.53609 & 0.009 \\
\hline
\end{tabular}

Leverage analysis is used to determine which variables that sensitively affect the level of sustainability of mangrove forest management (Karlina et al., 2016). The results of the leverage calculation indicate that there are four variables that are sensitive to the sustainability index of ecological dimension, namely: the capacity of mangroves, pollution, habitat alteration, and conservation zones. Damas coastal region experiences abrasion and river erosion due to the damage to mangrove forest ecosystems caused by the conversion of functions. The village government with Forest-Village Community Institution (Lembaga Masyarakat Desa Hutan or LMDH) have already sought to overcome the problems of abrasion and erosion by dredging the river whereas this problem still repeatedly occurred. Therefore, the effort made to overcome these problems is the conservation of mangrove ecosystems.

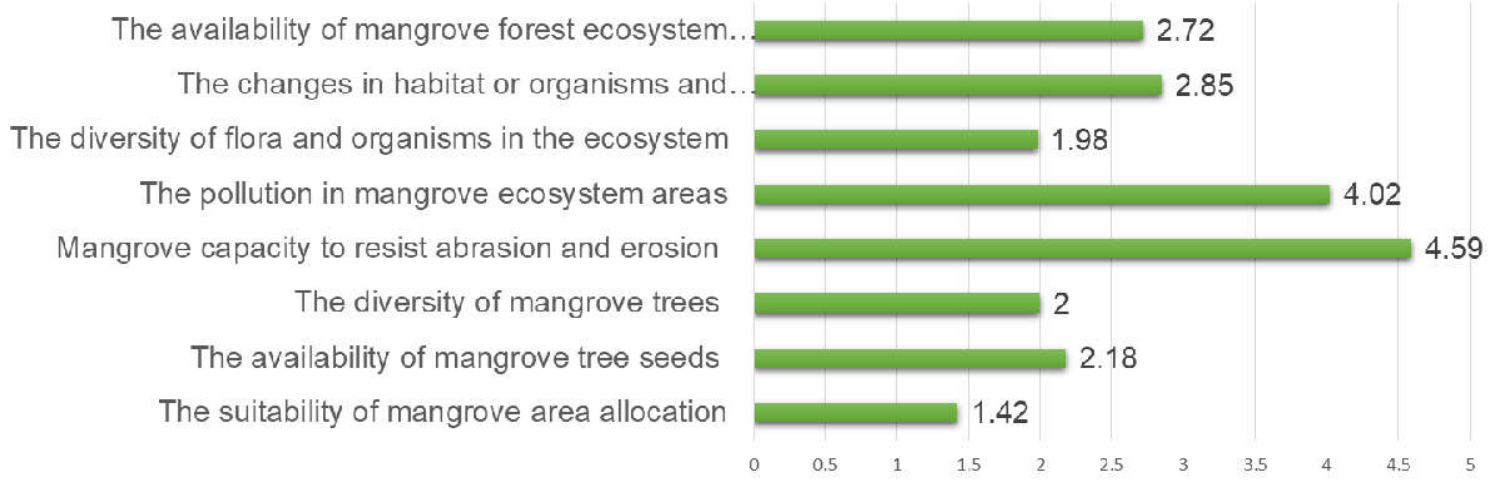

Figure 2 - Leverage Value of Ecological Dimension

The economic dimension that produces variables that are sensitive to changes in sustainability is job opportunities, inventory, utilization zones, and training. A good mangrove forest ecosystem will influence the job opportunities in the surrounding community. Zen et al., (2015) believes that the livelihoods in the Wonorejo Village related directly to the existence of mangrove ecosystem are mangrove-based food processors and fishermen in the surrounding area. According to Muhsimin et al. (2018), the cause of coastal communities to perform a destruction is the lack of alternative employment, the increasing number of people and necessities, as well as the condition of the people who do not have land outside the village area to develop agricultural business. Due to that matter, they do not have other options and will keep exploiting the mangroves.

An inventory of products produced from Damas coastal ecosystem is needed to measure economic value, product development, and as a basis for managing the conservation and utilization zones. Theresia et al. (2015) suggested that a counseling, education, and training on mangrove ecosystems is needed to be done to improve the sustainability status because human resources are the assets in the management of mangrove ecosystems. Mangrove fruit-based food processing training conducted by Purwanti et al., (2015) through the IbM Program caused the community to understand the function of mangrove plants as an alternative food material. In addition, IbM in 2017 understood that there is a link between mangrove forest ecosystems and coral reef ecosystems. 


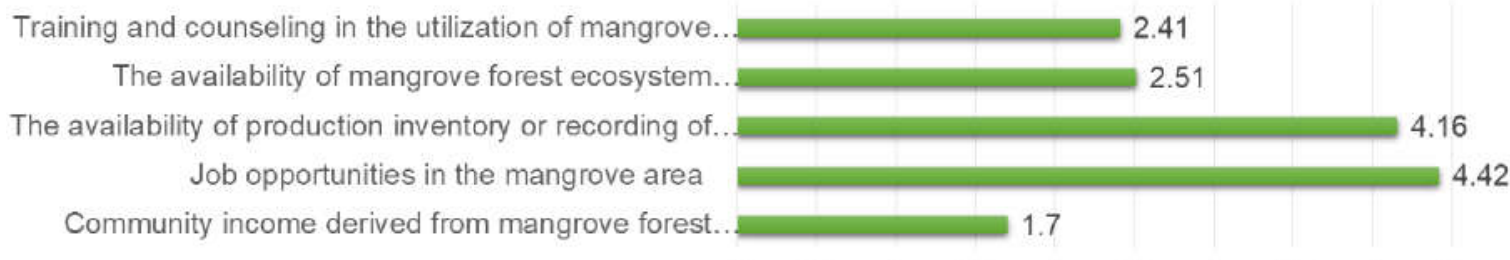

Figure 3 - Leverage Value of Economic Dimension

From the social dimension, the values that are sensitive to sustainability are public awareness, knowledge and perceptions, mechanisms for handling conflicts, and utilization conflicts. The management of mangrove forest ecosystems requires awareness from the coastal communities so as to increase the participation in the development. As explained by Muhsimin et al. (2018), direct community participation in every development activity is a form of social interaction that is very important in determining a success in such development. Purwanti et al., (2015) conducted a reforestation by 500 trunks of mangroves implemented by Pokmaswas Kejung Samudra based on the initiative of the Faculty of Fisheries and Marine Sciences team. This activity is part of the community service program that is within the effort to increase the knowledge of mangrove functions in a sustainable manner. This has had a positive impact on the awareness of the Karanggandu Village Government in 2016 which resulted in 200 mangroves planting. In addition, the role of the government (Trenggalek Regency) is needed to manage and to solve the conflicts over the use of mangrove forest ecosystems.

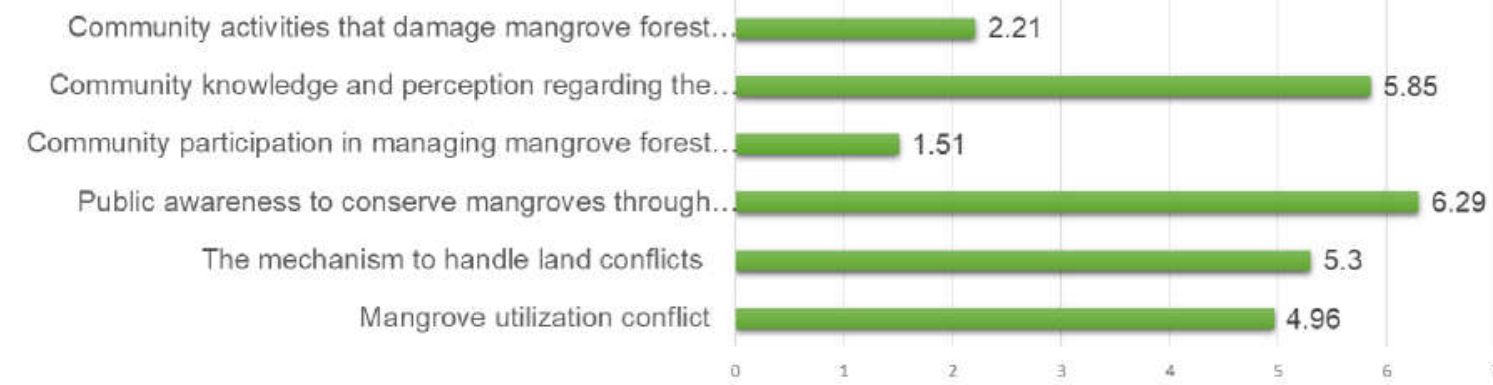

Figure 4 - Leverage Value of Social Dimension

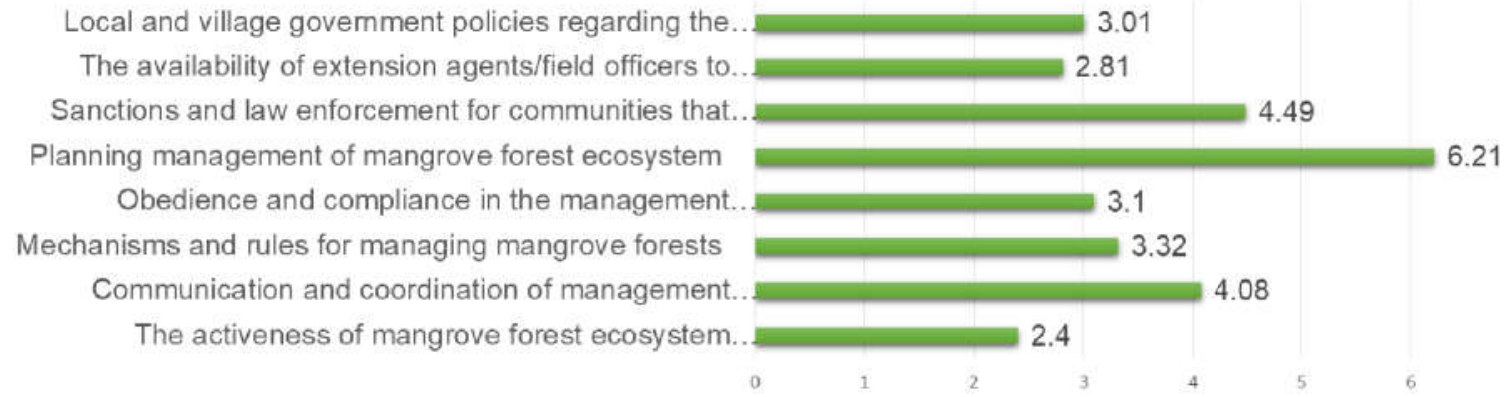

Figure 5 - Leverage Value of Legal and Institutional Dimension

The sensitivity of sustainability from the legal and institutional dimension is management planning, sanctions and law enforcement, communication and coordination of institutions, as well as mechanisms in management. The efforts needed to support success in managing mangrove forest ecosystems at Damas Beach are management plans that are made with the community. The law enforcement on Damas Beach for people who damage mangrove forest ecosystems is uncertain. This can be seen from the conversion of mangrove forests to plantations that are still developing. 
The communication and coordination system in managing the mangrove forest ecosystem is not established systematically. The lack of mechanisms and regulations in managing the coastal mangrove forest ecosystems make the people of Damas exploit and harm the ecosystem. In addition, local wisdom is needed in mangrove forest management because according to Muhsimin et al. (2018), if a local wisdom is practiced correctly and sincerely, the benefits can lead people to be more caring and responsible towards the environment.

\section{CONCLUSION AND SUGGESTIONS}

In summary, it can be said that the sustainability status of Damas Beach mangrove forest ecosystem is unsustainable in a multidimensional manner because the sustainability index of the ecological dimension shows a fairly sustainable category. On the other hand, in terms of economic, social, as well as legal and institutional dimension, the sustainability index is in the less sustainable category. This is due to the conversion of mangrove forests to coconut plantation. The variables that are most sensitive to ecosystem sustainability in each dimension include: abrasion and erosion, the development of alternative jobs, community awareness, and management plans.

From here, it is suggested that the government along with the community should conducted a mangrove rehabilitation, mangrove-based management and processing capacity improvement, deeper awareness building in concern to the functions and benefits of mangroves, as well as mangrove forest ecosystem management plans preparation.

\section{REFERENCES}

1. Duncan C, Primavera JH, Pettorellie N, Thompson JR, Loma RJA, Koldewey HJ. 2016. Rehabilitating Mangrove ecosystem sservices: A case study on the relative benefits of abandoned pond reversion from Panay Island, Philippines. Marine Pollution Bulletin 109 (2016) 772-782. www.elsevier.com/locate/marpolbul.

2. Eleanya K, Agbeja BO, ljeomah HM. 2015. Socio- Economic Importance of Mangrove Forests In Akassa Island of Niger Delta, Nigeria. PAT Journal No. 11 Vo.1 Pp 1-11. www.patnsukjournal.net/currentissue.

3. Eunike A., Dewi H., Silvie I.K., Andronicus. 2018. Sustainability Analysis of Beach and Mangrove Tourism in Clungup, Malang Regency of East Java. ECSOFiM: Economic and Social of Fisheries and Marine Journal. 06(01): 1-13. Available online at http://ecsofim.ub.ac.id/

4. Hue LTV and Scott S,. 2008. Coastal Livelihood Transitions: Socio-economic consequences of changing mangrove Forest management and Land Allocation in a Commune of Central Vietnam. Journal compilation Institute of Australian Geographers. Geographical Research No. 46 vol 1. Pp 62- 73.

5. Kapuangan H.D., Maryunani, Soemarno, Nuddin H. 2016. The sustainability of mangrove ecosystem and its implication for mangrove-based rural tourism development in southern Malang Regency, East Java, Indonesia. IOSR Journal of Environmental Science, Toxicology and Food Technology (IOSR-JESTFT) e-ISSN: 2319-2402,p- ISSN: 23192399. Volume 10, Issue 7 Ver. II (July 2016), PP 27-34.

6. Karlina E., Cecep K., Marimin \& Bismark, M. 2016. Analisis Keberlanjutan Pengelolaan Hutan Lindung Mangrove di Batu Ampar, Kabupaten Kubu Raya, Provinsi Kalimantan Barat. Jurnal Analisis Kebijakan Vol. 13 No. 3, Desember 2016: 201-219.

7. Paul US. 2006. Interelations among mangroves, The local economy and social sustainability: a review from a case study in North Brazil. CAB International. Environment and Livelihood in Tropical Coastal Zones.

8. Marimin. 2002. Teknik dan Aplikasi: Pengambilan Keputusan Kriteria Majemuk. Jakarta: Grasindo. 
9. Muhsimin, NS. \& Hariyadi. 2018. Status Keberlanjutan Pengelolaan Ekosistem Mangrove Di Wilayah Pesisir Desa Akuni Kecamatan Tinanggea Kabupaten Konawe Selatan. Jurnal Silvikultur Tropika Vol. 09 No. 1, April 2018, Hal 44-52.

10. Mukhlisi, Hendrarto, \& Hartuti P. 2014. Status Keberlanjutan Pengelolaan Hutan Mangrove Di Desa Sidodadi Kecamatan Padang Cermin Kabupaten Pesawaran Provinsi Lampung. Jurnal Geografi Volume 11 No. 1: 58-70.

11. Purwanti, P., Dwi S. \& Edi S. 2015. IbM Pengelolaan Hutan Mangrove. Universitas Brawijaya.

12. Purwanti P., Susilo E. \& Setijawati, D. 2016. Analisis Pengembangan Usaha Berbasis Mangrove Di Pantai Damas Kabupaten Trenggalek. JIAT Vol. 2 No.1 Pp 217-225.

13. Purwanti P, Susilo E, Indrayani E. 2017. Household Economic Activities of Coastal Resource Users' Community in Cengkrong Coastal Area, Prigi Bay, Trenggalek. Russian Journal of Agricultural and Socio-Economic Sciences. 2(62) February 2017. Pp 91-99. Crossref DOI: 10.18551/rjoas.2017-02.11.

14. Rahman MAA \& Asmawi MZ. 2016. Local Residents' Awareness towards the Issue of Mangrove Degradation in Kuala Selangor, Malaysia. Procedia - Social and Behavioral Sciences 222 (2016) $659-667$.

15. Susilo E, Purwanti P, Fattah M. 2017. Analysis on Economical and Ecological Potential benefits of Artificial Coral Reefs Planting Activities. Russian Journal of Agricultural and Socio-Economic Sciences, RJOAS 12(72) December 2017. Pp 268. https: //doi.org 10.18551/rjoas.2017-12.37.

16. Susilo, Pudji P. \& Riski A.L. 2015. Keberlanjutan "Kejung Samudra" Dalam Pengelolaan Dan Pemanfaatan Sumberdaya Mangrove Di Pancer Cengkrong Dan Damas, Pantai Prigi, Trenggalek. J. Kebijakan Sosek KP Vol. 5 No. 2: 19-25.

17. Theresia, Mennofatria B., \& Niken T.M.P. 2015. Status Keberlanjutan Pengelolaan Ekosistem Mangrove Di Taman Nasional Sembilang Kabupaten Banyuasin Provinsi Sumatera Selatan. Jurnal IImu dan Teknologi Kelautan Tropis, Vol. 7, No. 2, pp.703-714

18. Wibowo A.B., Sutrisno A., \& Bambang Y. 2015. Status Keberlanjutan Dimensi Ekologi Dalam Pengembangan Kawasan Minapolitan Berkelanjutan Berbasis Perikanan Budidaya Air Tawar Di Kabupaten Magelang. Jurnal Saintek Perikanan Vol.10 No.2:107113.

19. Zen L.Z., Dudung D., \& Nyoto S. 2015. Strategi Mata Pencaharian Masyarakat Berkelanjutan Pada Ekosistem Mangrove Di Wonorejo, Kota Surabaya. Risalah Kebijakan Pertanian dan Lingkungan Vol. 2 No. 3: 230-242. 